\title{
ИСПОЛЬЗОВАНИЕ ТВОРЧЕСКИХ ЗАДАНИЙ ПРИ ПОДГОТОВКЕ К ПИСЬМЕННОЙ ЧАСТИ ЕГЭ ПО ФРАНЦУЗСКОМ ЯЗЫКУ
}

\author{
Ганго Анна Александровна \\ студент \\ Научный руководитель: Лантикова Ольга Валентиновна \\ старший преподаватель кафедры \\ европейских языков и культур \\ ФГБОУ ВО «Псковский государственный университет»
}

\begin{abstract}
Аннотация: В представленной статье освещаются способы подготовки к письменной части ЕГЭ по французскому языку с применением игровых технологий, приведены примеры практических творческих заданий, способствующих формированию речевых навыков и умений, необходимых для успешного прохождения письменной части итоговой аттестации по французскому языку.
\end{abstract}

Ключевые слова: подготовка, ЕГЭ, письменная часть, творческие задания, мотивация.

\section{THE USE OF CREATIVE TASKS IN PREPARATION FOR THE WRITTEN PART OF THE UNIFIED STATE EXAM IN FRENCH LANGUAGE}

\section{Gango Anna Alexandrovna Scientific adviser: Lantikova Olga Valentinovna}

\begin{abstract}
The article highlights the ways of preparing for the written part of the Unified State Exam in French using game technologies, provides examples of practical creative tasks that contribute to the formation of speech skills and skills necessary for the successful completion of the written part of the final certification in French language.
\end{abstract}

Keywords: preparation for the written part of the Unified State Exam, creative tasks.

Единый государственный экзамен (ЕГЭ) - важный этап в жизни каждого старшеклассника. Целью государственной итоговой аттестации является определение соответствия результатов освоения обучающимися основных образовательных программ среднего общего образования 
соответствующим требованиям федерального государственного образовательного стандарта [1].

В фокусе нашего исследования находится подготовка к одному из разделов письменного блока ЕГЭ по французскому языку - «Письмо».

Однако было бы неправильно упустить этап подготовки к разделам, предшествующим разделу «Письмо».

Согласно спецификации контрольных измерительных материалов для проведения в 2022 году единого государственного экзамена по иностранным языкам, письменная часть поделена на четыре блока по содержанию, видам умений и способам действий:

1. Раздел «Аудирование» проверяет понимание содержания устного высказывания [2].

2. Раздел «Чтение» включает в себя художественные, научнопопулярные и публицистические тексты. Данный раздел направлен на проверку понимания экзаменуемым основного содержания текста, а также понимания структурно-смысловых связей в тексте [2].

3. Раздел «Грамматика и лексика» направлен на проверку навыка употребления основных грамматических форм французского языка в контексте [2].

4. Раздел «Письмо» проверяет умение правильно реализовать с помощью языковых средств коммуникативные намерения [3].

Обучение письму и письменной речи занимает важное место во всей системе обучения иностранному языку, в том числе, и в подготовке к единому государственному экзамену. Умение письменно фиксировать новый языковой материал способствует его запоминанию, создаёт слухо- и зрительномоторный образы, эталон изучаемого явления в целом, также, даёт возможность вводить в учебный процесс и в подготовку к ЕГЭ письменные упражнения для тренировки изученного материала [4].

Заметим, что на подготовку к разделу «Письмо» стали меньше уделять времени и внимания, поскольку недавно была введена устная часть ЕГЭ и на нее бросили много сил.

Мы полагаем, что необходимо оптимизировать процесс подготовки именно к разделу «Письмо» и считаем, что нужно разработать такую систему подготовки, которая позволит за минимальное количество времени достигнуть максимального результата. Важно сделать подготовку интересной 
и творчески подойти к составлению тренировочных заданий, для этого, по нашему мнению, нужно привлечь интернет-технологии, игры и квесты.

Обучение письменной речи и подготовка к выполнению заданий раздела «Письмо» на ЕГЭ должны сочетаться с другими видами речевой деятельности:

- аудированием (диктанты, изложения и т.д.);

- чтением (упражнения после текста, ответы на вопросы, завершение рассказа и т.д.);

- говорением (интервью с последующим письменным изложением информации, парное или групповое обсуждение с записью аргументов обеих сторон).

Важно отметить, что для более продуктивной подготовки к разделу «Письмо», нужна мотивация, которую требуется постоянно поддерживать и укреплять. Необходимо заинтересовать учащихся, подчеркнуть важность овладения письменной речью.

Раздел «Письмо» состоит из двух заданий с развёрнутым ответом - 39, 40 (40.1 или 40.2).

В задании 39 представлен отрывок из электронного письма собеседника (друга), в котором он рассказывает о каких-либо событиях из своей жизни. Учащемуся предлагается сформулировать электронное письмо личного характера в ответ на письмо-стимул зарубежного друга по переписке, соблюдая все правила его написания.

Для тренировки «личного письма» можно использовать следующий тип упражнения:

Игра «Дружеская переписка».

Задачи учителя:

- сделать «почтовый ящик»;

- погготовить карточки с именами и фамилиями участников

Правила игры:

- Жеребьёвка (учащимся предлагается вытащить карточку с именем и фамилией «друга по переписке»);

- Далее, ученикам нужно написать личное письмо объёмом 100-140 слов (по всем правилам его написания) на тему «Описание своей внешности и интересов» и положить его в почтовый ящик. Важным условием является то, что учащийся не должен подписывать письмо своим именем (он может подписаться как «аноним»); 
- Затем, когда учащиеся получат письмо от «анонима», их задачей будет отгадать по описанным признакам и спектру интересов, от кого они получили письмо;

- Как только они узнают, от кого письмо (уточняют, правильно ли отгадали), учитель объявляет, что «Теперь это ваш друг по переписке, который ждёт от вас ответное письмо»;

- Затем, учитель задаёт новую тему;

- «Переписка» продолжается.

Стоит отметить, что данную игру необходимо проводить небольшими периодами, т.е. чередовать подготовку к личному письму с подготовкой к сочинению-рассуждению.

В задании 40 письменной части ЕГЭ по французскому языку учащемуся необходимо создать развёрнутое письменное высказывание с элементами рассуждения на основе таблицы или диаграммы и выразить своё мнение по теме проекта. Задание 40 делится на 40.1 и 40.2. Экзаменуемому нужно выбрать один из предложенных вариантов задания, письменно прокомментировать данные в таблице или диаграмме и высказать свое мнение по теме проекта, не нарушив объём 200-250 слов.

Эссе должно быть чётко структурировано и содержать:

- тематику проекта;

- 2-3 пункта из таблицы или диаграммы;

- сравнение 1-2 наиболее важных фрагмента информации;

- выявление проблемы и предложение её решения;

- заключение.

Благодаря творческому подходу, подготовка к заданию высокого уровня сложности - сочинению, может стать увлекательной и интересной для старшеклассников. Примером творческого задания может стать создание проектов-газет на различные темы:

1. С помощью жребия учащиеся объединяются в 3-4 команды по 4-5 человек, в зависимости от количества учеников в классе;

2. Затем, каждой команде учитель раздаёт карточки с темами проектов. На заранее подготовленных карточках изображена та или иная статистика в виде таблицы или диаграммы по теме проекта.

3. Каждый член команды формулирует ту или иную часть сочинения, учащимся даётся около 20 минут.

4. Затем, командам необходимо на ватмане написать получившееся 
сочинение (каждый член команды пишет свою часть) проиллюстрировать тему проекта.

5. Защита проекта:

- Подсчёт слов

- Проверка структуры сочинения

Отметим, что учитель исполняет роль главного редактора. Именно он контролирует весь процесс выполнения задания.

Таким образом, мы сделали вывод, что тренировка выполнения заданий раздела «Письмо» в ЕГЭ по французскому языку имеет одну из ведущих ролей при подготовке к экзамену в целом. Это кропотливый труд, но, при правильной организации, он даёт стабильно положительные результаты и предотвращает потерю баллов в письменной части ЕГЭ по французскому языку.

\section{Список литературы}

1. Спецификация контрольных измерительных материалов для проведения в 2022 году единого государственного экзамена по иностранным языкам (английскому, немецкому, французскому, испанскому языкам)// URL:https://fipi.ru/ege/demoversii-specifikacii-kodifikatory\#!/tab/151883967-11 (дата обращения: 13.12.2021)

2. 4ЕГЭ - URL: https://4ege.ru/franc/62612-demoversija-ege-2022-pofrancuzskomu-jazyku.html (дата обращения: 15.11.2021).

3. Демоверсии ЕГЭ 2022 по французскому языку [Электронный pecypc]. URL: https://www.kp.ru/putevoditel/ege/demoversii-ege-po-frantsuzsko mu-yazyku/ (дата обращения: 28.11.2021).

4. Миньяр-Белоручев Р.К. Методика обучения французскому языку / Миньяр-Белоручев Р.К. - М.: Просвещение, 1990. - 224 с.

(C) А.А. Ганго, 2021 